\title{
Canadian Lung Association Research Update 2003
}

\section{Mise à jour de la recherche 2003 de l'Association pulmonaire canadienne}

L ast summer, I wrote an article to share information with the members of the Canadian Lung Association's (CLA's) professional societies on decisions made by the CLA affecting its research funding for the fiscal year 2002 to 2003. I would like to provide our societies and the research community with an update on our research activities over the past year.

For more than 30 years, the CLA has funded a research program that has been accessible to the Canadian Thoracic Society, the Canadian Nurses' Respiratory Society and the Canadian Physiotherapy Cardio-Respiratory Society. We are extremely proud of our contributions, as well as the partnerships that have been formed with corporations to further fund research in the field of lung health.

As I mentioned last year, our research fund had been declining due to a number of factors, including the fact that the CLA was providing more grant funding than its revenues permitted. It was imperative that the Board of Directors make decisions to ensure sustainability of the fund. During the past year, a number of steps have been taken to get the research program back on track and to begin to build the fund.

The Board passed a motion that it would not spend more than it receives in research assessments from the provincial Lung Associations. (This is how the program is funded.) Therefore, if a provincial Lung Association is facing financial difficulties and cannot pay its assessments to the CLA, the fund will be reduced by that amount. It was also decided that should the full amount of research grants not be used and funds be returned to the CLA, those funds will be used to build the fund, rather than redistributed, in a given year. Further, any increases to the provincial assessments will be used to build the fund. During this fiscal year, the research assessments were increased by $4 \%$.

The CLA Research and Finance Committees are currently working on strategies to build the fund to an acceptable, sustainable level. During the coming year, a number of options will be reviewed and considered. The Research Committee represents all of the CLA's societies with the presidents and research chairs of each. This also includes the Respiratory Therapy Society, which, until the current fiscal year, had not received research funding from the CLA. This ensures that all professional societies have input into the decisions that will affect the research fund.

Last August, I recommended to the Board that the CLA needed to hire a staff person to assume two responsibilities: to enhance research partnerships and to carry out the advocacy role of the organization. We hired a Director of Public Issues in April 2003.
T 'été dernier, j'ai rédigé un article pour partager Lde l'information avec les membres des sociétés professionnelles de l'Association pulmonaire canadienne (APC) sur les décisions prises par l'APC qui avaient des incidences sur ses subventions de recherches pour 2002-2003. Je tiens à mettre ces sociétés et la collectivité de la recherche au courant des activités de la recherche depuis un an.

Depuis plus de 30 ans, l'APC subventionne un programme de recherche accessible à la Société canadienne de thoracologie, à la Société canadienne des infirmières en santé respiratoire et à la Société de physiothérapie cardiorespiratoire du Canada. Nous sommes extrêmement fiers de notre apport et des partenariats noués avec des entreprises pour mieux subventionner la recherche en santé pulmonaire.

Comme je l'ai dit l'an dernier, nos fonds de recherche baissaient en raison de divers facteurs, y compris le fait que l'APC accordait des subventions plus élevées que ses revenus le permettaient. Il était impératif que le conseil d'administration prenne des décisions pour garantir la viabilité du fonds. Depuis un an, plusieurs mesures ont été prises pour remettre le programme de recherche sur la bonne voie et pour commencer à faire fructifier un fonds.

Le conseil a adopté une résolution selon laquelle il ne dépenserait pas plus qu'il ne recevrait en cotisations de recherche de la part des associations pulmonaires provinciales. (C'est ainsi que le programme est subventionné.) Par conséquent, si une association pulmonaire provinciale affronte des difficultés financières et qu'elle ne peut pas verser ses cotisations à l'APC, le fonds sera réduit de cette somme. Il a également été décidé que si le total des subventions de recherche n'est pas utilisé et que des sommes sont renvoyées à l'APC, ce montant servira à constituer le fonds et ne sera pas distribué. De plus, toute augmentation des cotisations provinciales permettra de faire fructifier le fonds. Pendant le présent exercice, les cotisations de recherche ont augmenté de $4 \%$.

Les comités de la recherche et des finances de l'APC travaillent à des stratégies pour constituer le fonds afin qu'il atteigne un niveau acceptable et durable. Au cours du prochain exercice, plusieurs possibilités seront évaluées et envisagées. Le comité de la recherche représente toutes les sociétés de l'APC et se compose des présidents des conseils et des présidents de la recherche de chacune d'elles. Il inclut également la Société de la thérapie respiratoire, qui, jusqu'au présent exercice, n'avait pas reçu de subventions de l'APC. Ainsi, toutes les sociétés professionnelles participent aux décisions qui influeront sur le fonds de recherche.

En août 2002, j'ai recommandé au conseil que l'APC embauche un employé qui assumerait deux responsabilités : 
Since the Director of Public Issues was hired, we have accomplished much in a short period of time. We have developed an excellent working relationship with the Canadian Institutes for Health Research (CIHR), and we are looking at new and innovative ways of partnering. To date, one provincial Lung Association has sent additional funding (above and beyond its regular research assessment) to partner with the CIHR. This resulted in leveraging several million dollars in research funding.

Several other provincial Lung Associations are interested in leveraging further research funding on a national basis, and we are currently working on developing those partnerships. We will continue to look at new ways of ensuring that the lung health community receives more access to national research funding.

By working with the CIHR to broker much larger pools of funding, more resources can be directed to the lung health research community. The question could be asked, "Would that money have naturally flowed back to lung health researchers in the various provinces regardless of The Lung Association's partnership?" The answer is not necessarily.

Without The Lung Association's ability to partner with the CIHR on research funding, there is no guarantee that the lung health community will receive funding. Other partners may prefer to fund applications more in line with their direct interests. For example, through partnering, we have been able to help support grants that individually bridge multiple arenas such as genetic, circulatory and respiratory health. If all applications received are ranked and a number are deemed fundable, other partners may choose to focus on applications addressing the genetic or circulatory side of the requests for applications, but not the respiratory side. Our partnership ensures that in such a case, respiratory applications would indeed be funded.

These larger strategic initiatives are of national scope and importance to Canadians, are multidisciplinary in nature spanning multiple regions and institutions - and include many specialist profiles. They are truly in the interest of 'best science' and are commissioned to solve complex research problems. Ideally, the focus is on specific problems wherein the research will have an impact on health care, health services or a technology application.

It also stands to reason that by forming a closer relationship with the CIHR, our community will be heard. We are participating in the CIHR strategic planning meetings. As a member of those meetings, we are able to determine future areas of opportunity and continue to represent the best interests of the lung health community.

We are looking at opportunites to establish requests for applications in which our community is particulary interested. We continue to investigate further national partnering opportunites, including those with other national health organizations, to enhance the ability of the lung health community to access additional research funding.

Research interests will also be addressed through our participation in the Health Charities Council of Canada. This year we also joined the Council for Health Research in Canada. By being a member, we are a part of a coalition of health organizations that will hold the federal government's feet to the fire favoriser les partenariats de recherche et s'assurer de la défense d'intérêts de l'organisme. Nous avons embauché un directeur des affaires publiques en avril 2003.

Depuis cette embauche, nous avons beaucoup accompli en peu de temps. Nous avons amorcé une excellente relation de travail avec les Instituts de recherche en santé du Canada (IRSC), et nous cherchons des modes de partenariat novateurs. Jusqu'à présent, une association pulmonaire provinciale a envoyé des sommes supplémentaires (en plus de sa cotisation habituelle pour la recherche) afin de nouer un partenariat avec les IRSC. Cette initiative a permis d'obtenir quelques millions de dollars de subventions de recherche.

Plusieurs autres associations pulmonaires provinciales sont intéressées à aller chercher plus de subventions de recherche à l'échelle nationale, et nous sommes à élaborer de tels partenariats. Nous continuerons à étudier de nouvelles manières de garantir que la collectivité de la santé pulmonaire ait un meilleur accès aux subventions de recherche nationales.

Grâce au travail avec les IRSC visant à canaliser de plus vastes bassins de financement, plus de ressources peuvent être orientées vers la collectivité de la recherche en santé pulmonaire. On peut se demander si ces fonds auraient été versés aux chercheurs en santé pulmonaire des diverses provinces sans le partenariat avec l'APC. La réponse, c'est pas nécessairement.

Sans la capacité de l'APC à s'associer aux IRSC pour ce qui est des subventions de recherche, rien ne garantit que la collectivité de la santé pulmonaire recevra des subventions. D'autres partenaires pourraient préférer financer des applications plus conformes à leurs intérêts directs. Par exemple, grâce au partenariat, nous avons pu contribuer à soutenir des subventions qui touchent divers domaines, tels que la génétique, la santé du système circulatoire et la santé pulmonaire. Si toutes les demandes reçues sont classées et qu'un certain nombre d'entre elles est jugé subventionnable, d'autres partenaires peuvent préférer se concentrer sur des applications qui touchent l'aspect génétique ou circulatoire des demandes plutôt que l'aspect pulmonaire. Notre partenariat permet d'assurer que dans un tel cas, les applications pulmonaires seront bel et bien subventionnées.

Ces initiatives stratégiques plus vastes sont de portée et d'importance nationales pour les Canadiens. Elles sont de nature multidisciplinaire, car elles touchent diverses régions et divers établissements, et elles incluent de nombreux profils de spécialistes. Elles sont vraiment dans l'intérêt de la meilleure science qui soit et sont commandées pour résoudre des problèmes de recherche complexes. D'un point de vue idéal, il faut se concentrer sur des problèmes précis pour que les recherches aient des répercussions sur les soins, les services de santé ou une application technologique.

Il semble également évident qu'en entretenant une relation plus étroite avec les IRSC, notre collectivité sera entendue. Nous participons aux réunions de planification stratégique des IRSC. À titre de membre de ces réunions, nous pouvons déterminer les futures fenêtres de possibilité et continuer de représenter les meilleurs intérêts de la collectivité de la santé pulmonaire.

Nous cherchons des occasions de présenter des demandes de subvention auxquelles notre collectivité sera particulière- 
to ensure that appropriate funding for research is achieved. The Council has been successful during the past several years in lobbying the federal government to increase funding for research.

This fall, we will also be working with our corporate sponsors to develop new research partnerships and to enhance those that currently exist.

From an advocacy perspective, we have had several opportunities to make our position heard by the Federal Minister of Health, Anne McLellan. We have been able to speak to her directly about the need for Health Canada to ensure that the budget for the CIHR for research funding reaches the government's promise of CDN $\$ 1$ billion. Currently, there is a CDN\$350,000 shortfall, and we do not see a commitment from the federal government to reach that level in a reasonable time frame. We will continue to focus our efforts in this area.

We have plans to hold a Lung Health Day on Parliament Hill, most likely in March 2004. We will ensure that the CLA's research priorities are highlighted at this event, and we look forward to participation from our professional societies.

We have come a long way in one year. I look forward to further advancing the CLA's agenda for lung health research, both from a partnership and an advocacy perspective. I look forward to continuing to build our research fund to a sustainable level and to working with you to realize our mutual goals.

Deirdre Freiheit President 8 CEO, The Lung Association ment intéressée. Nous continuons d'étudier les possibilités de partenariats nationaux, y compris ceux avec d'autres organismes nationaux en santé, afin d'accroître la capacité de la collectivité de la santé pulmonaire à accéder à des fonds de recherche supplémentaires.

Les intérêts de la recherche seront également abordés grâce à notre participation au Conseil canadien des organismes bénévoles en santé. Cette année, nous avons également adhéré au Conseil pour la recherche en santé du Canada. En devenant membre, nous participons à une coalition d'organismes en santé qui tiendra le gouvernement fédéral sur le qui-vive afin que des fonds suffisants soient attribués à la recherche. Ces dernières années, le Conseil a réussi à exercer suffisamment de pression pour que le gouvernement fédéral accroisse le financement de la recherche.

Cet automne, nous travaillerons également avec nos sociétés commanditaires à élaborer de nouveaux partenariats de recherche et à améliorer ceux déjà en place.

Du point de vue de la défense d'intérêts, nous avons plusieurs possibilités de nous faire entendre par la ministre de la Santé fédérale, Ann McLellan. Nous avons pu lui parler directement de la nécessité que Santé Canada fasse passer le budget de financement de la recherche des IRSC à un milliard de dollars canadiens, conformément à la promesse du gouvernement. Pour l'instant, il reste un manque à gagner de 350000 dollars, et le gouvernement fédéral ne s'est pas engagé à atteindre ce plafond dans un délai raisonnable. Nous continuerons d'axer nos efforts dans ce secteur.

Nous avons l'intention de tenir une journée de la santé pulmonaire sur la colline du Parlement, probablement en mars 2004. Nous nous assurerons que les priorités de recherche de l'APC y soient soulignées, et nous comptons sur la participation de nos sociétés provinciales.

Nous avons parcouru beaucoup de chemin en un an. J'espère faire progresser davantage le programme de l'APC en matière de recherche en santé pulmonaire, tant du point de vue des partenariats que de la défense d'intérêts. J'espère aussi continuer à constituer un fonds de recherche permanent et à travailler avec vous à la réalisation de nos objectifs communs.

Deirdre Freiheit Présidente et PDG, Association pulmonaire canadienne 


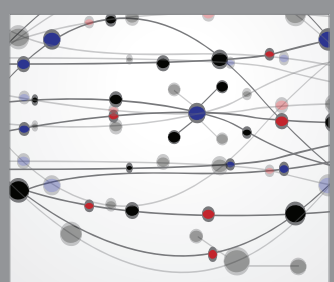

The Scientific World Journal
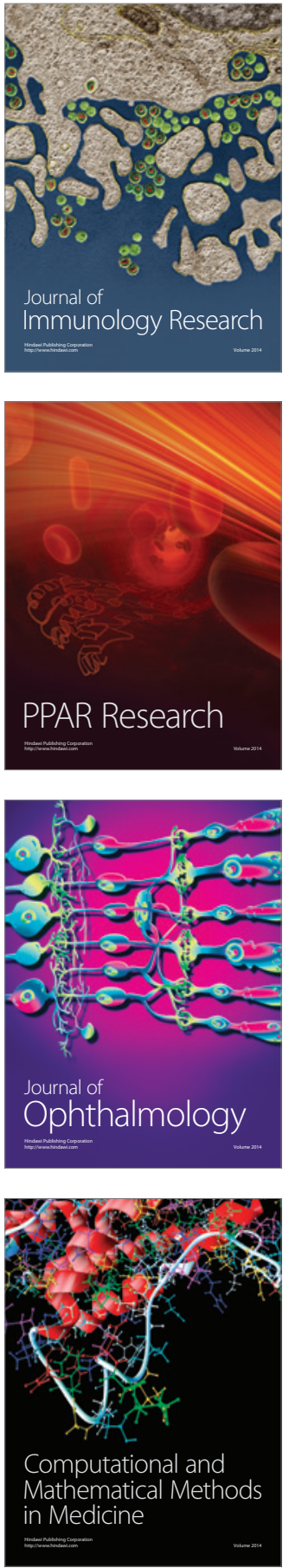

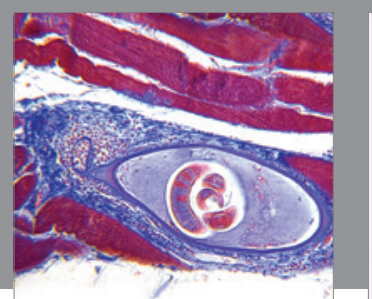

Gastroenterology Research and Practice

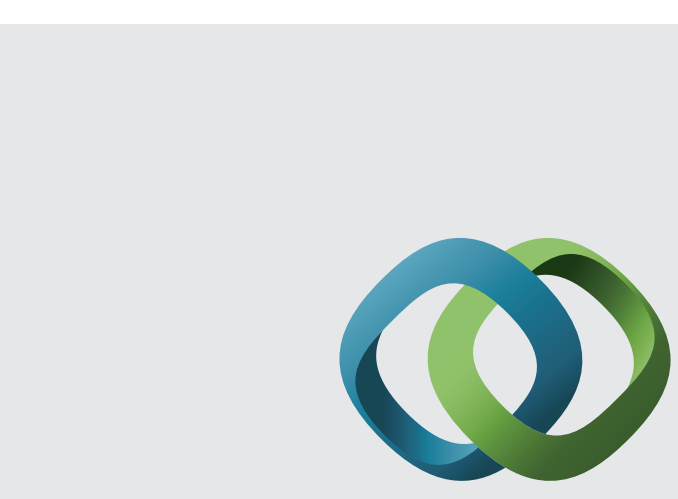

\section{Hindawi}

Submit your manuscripts at

http://www.hindawi.com
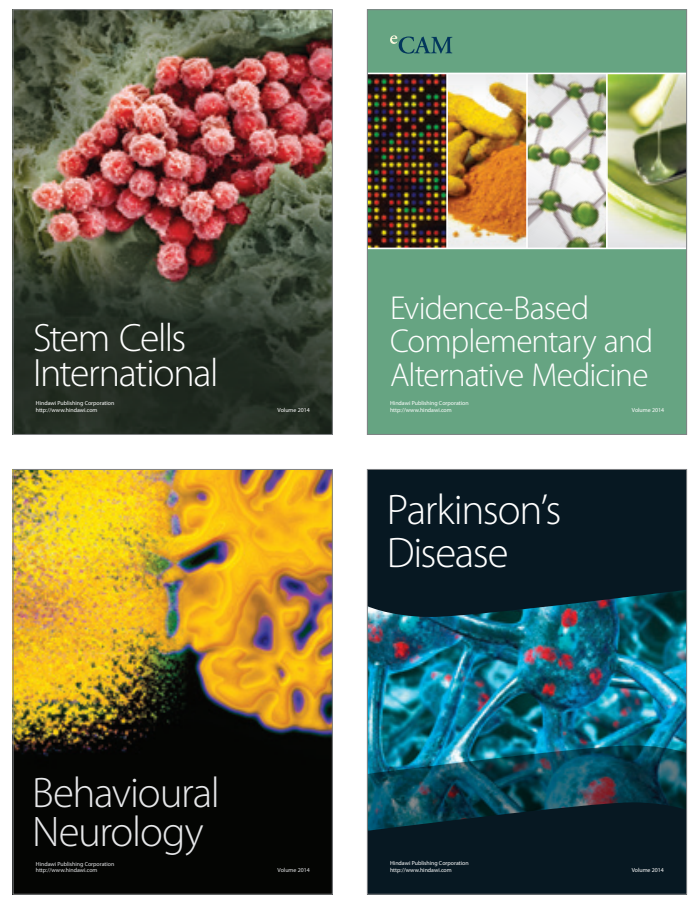
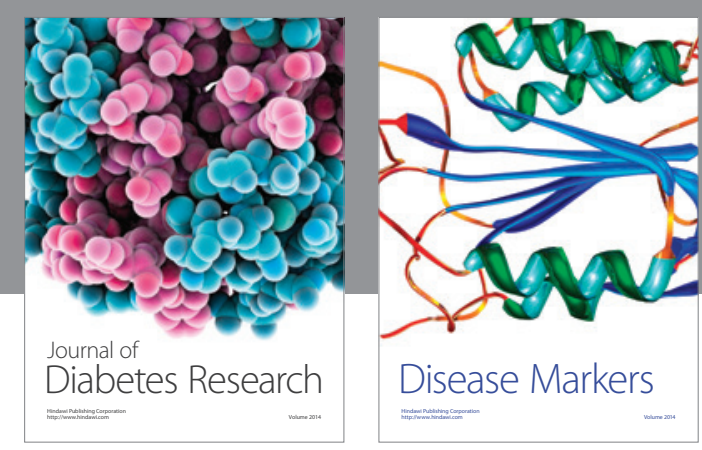

Disease Markers
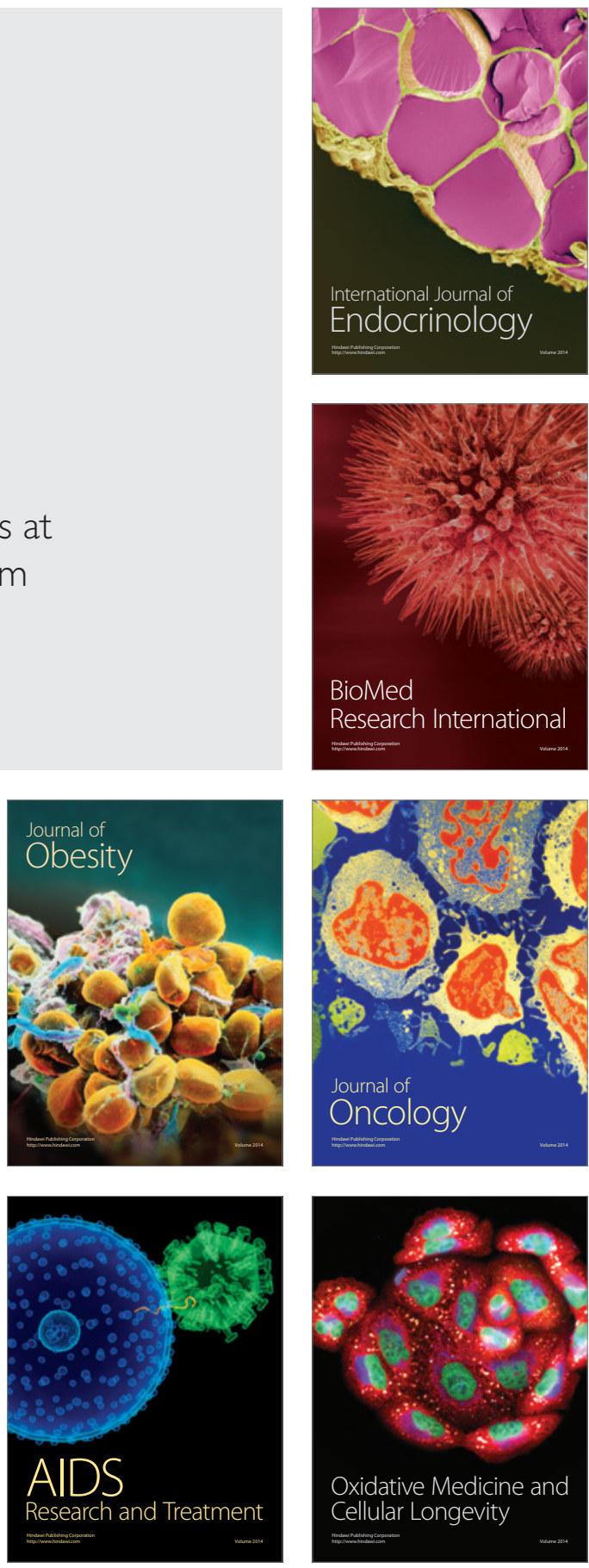